\title{
Four Conflicts - Four Mandates Comparative Analysis of the Conflicts and Mandates of United Nations Peacekeeping Missions in Western Sahara, Angola, Namibia and Central African Republic
}

\author{
HARKAI István ${ }^{1}$
}

\begin{abstract}
During the $20^{\text {th }}$ century, the United Nations led several peacekeeping missions into Africa, where civil wars and armed conflicts among states have followed each other. These conflicts differed in many aspects from each other, and the UN tried to give several answers to heal the conflicts. This essay attempts to present and compare these conflicts and the UN missions through the case of three states and a colony, Angola, Namibia, the Central African Republic, and Western Sahara. Keywords: Uti possidetis, Angola, Namibia, Central African Republic, Western Sahara, UN mandate, peacekeeping, human rights
\end{abstract}

\section{Introduction}

If we are observing the countries and conflicts of Africa, the first typical particularity is, that the nations of Africa reached the highest level of self-determination relatively late, only in the $20^{\text {th }}$ century. The second characteristic is that after the end of the colonial era, in most of the countries, dictatorships were formed, and later on civil wars exploded. The reasons for these phenomenon are arborescent, mainly caused by the deep poverty, the underdeveloped economy and the disadvantageous borderlines enclosing different ethnic groups, religious denominations, tribes and clans into one country. [1: 65] In this essay I am going to investi- gate four conflicts in four African countries and the mandates of those peacekeeping missions which were adopted to resolve the situations in the analyzed conflicts.

\section{Possession of Africa and the "Uti Possidetis"}

Before I start to analyze the four conflicts, we have to discuss one of the important rules of international law, and a document which is considered to be the written manifestation of the division of Africa by the imperialist powers. To understand the crises burdening Africa, first we have to check the borders separating African nations from each others, since the inherit- ed conditions from the colonial times influence adversely the relationships among states in Africa.

1 dr. jur., e-mail: harkai.istvan89@gmail.com 
As many others, in my first paper about Western Sahara I also believed that Africa was divided at the Berlin Conference by the great powers, although this is not completely true. [2] The scramble for Africa began hundreds of years ago, when Portuguese and later Dutch, English and French sailors visited the coasts of Western, Southern and Eastern Africa, then established bases and started to trade for slaves and other goods. The great powers in the $19^{\text {th }}$ century followed the borders of the sphere of influence, which were already stabilized. In this process the Berlin Conference was only an episode.

In Berlin, the contracting parties settled six main questions: facilitate the free trade in the basin of the Congo River, prohibition and persecution of the slave-trade, military neutrality of the Congo basin, free navigation on the Congo and the Niger rivers and their affluents, establishing effective military-administrative institutions for the sake of good governance of newly conquered provinces. [3]

However it is true, the General Act of the Congress of Berlin has pronounced that under the principle of continuity those powers who conquer a seashore region have the right to demand territories in the inner part of the continent, they are allowed to establish administra- tion, but they have to announce this to the other colonizing powers, and last but not least, it has to grant free transit and trade. [4]

Gaining possession over internal territories usually happens by occupation or protectorate treaties. [5] In case of Spanish Sahara, the Spanish king made a contract for a protectorate with the chieftains of Saharawies. [6] After the sphere of interest emerged, the great powers drew the internal borders in bilateral settlements, later on these lines became the borders of the independent states. In case of Western Sahara, the border-line separating the Spanish lands from the French, was drawn on the $27^{\text {th }}$ of June in 1900 with a bilateral treaty between the Spanish Kingdom and France. [7]

Treaties related to African internal border-lines are numerous; to give only a few exam- ples we can mention the following agreements. During colonial times the Central African Republic was a part of a greater, contiguous French colony, named French Equatorial Africa. The borders of this entity were settled in different treaties among the neighboring powers and France in 1894 and 1899. The boundaries of Angola were also drawn up in bilateral treaties. The British Empire and Portugal came to an agreement in 1893 about the separation of neighboring lands and the zone of influence in the Zambezi region. [8] The competing powers established the borders of Namibia in several agreements. The famous one was the Heligoland-Zanzibar Treaty between the German and the British Empires. [9]

As we have seen above, drawing border-lines in the $19^{\text {th }}$ century was done according to the interest of great powers, deprived of all the aspects of ethnic interests. But why should they have to pay attention to the ethnic factors, when in the second half of the $19^{\text {th }}$ century, the people of the "black continent" - apart from a couple of independent entities - were so far from the right to self-determination or independence. After World War II, disintegration of the European colonial empires sped up, as a result, the new independent states inherited the former provincial borders with all of their problems. To avoid the debates and conflicts over border-lines, the international community accepted an obligatory and pretty inelastic rule, the so called principle of "uti possidetis, ita possideatis", which declared, that the entity becom- ing newly independent has to "possess its own territory, as it always did", so they have to keep the borders inherited from the colonial era. [10] The principle was created in the times of ancient Rome by Roman civil law, but it used to be used in private legal relations, not in 
the affairs of states. 1810 was the first time, when it was applied in the relations of states, when the Spanish colonies of Latin America earned their independence. [11]

In Africa as a principle, the uti possidetis was used firstly in the Sixties. Based on this principle the International Court of Justice adjudged in the case of the border-dispute of Burkina Faso and Mali in 1986, that the essence of the principle is to keep the borders in the condition they were in the moment of earning self-determination. [11] The ICJ ${ }^{2}$ emphasized, the principle of uti possidetis not only as a regional norm of international law, but a general one, closely linked to the independence of states, wherever on Earth. [11] The ICJ also point- ed to the use of the principle as a mandatory rule of customary international law, which needs to be respected by all the parties of international affairs. This is the only way to maintain the independence and stability of the newly emerged states, and this is the only opportunity to protect them from the successionist movements. [4] Although the principle of uti possidetis is quite strict, deviations are possible, if both of the disputing parties agree on the modification of border-lines. [12]

\section{The Four Conflicts}

The fact that many of African states have to face civil wars springs from the colonial heritage and underdevelopment of states on the continent. There are places, where people are still living under colonial rule, we can find some where ethnic or religious clashes led to civil war, but also there are states with relatively thriving economies and more or less well operating political and administrating systems.

\section{Western Sahara}

Our first example demonstrates a short history of a territory, where the citizens are still un- der colonial rule, they have not reached the phase of complete self-determination yet, they are still waiting for the time, when they finally can vote and decide about their future. The Spanish sailors appeared in the region during the $15^{\text {th }}$ century. After conquering the

Canary Islands, Spain entered into a relationship with the inhabitants of Sahara. [7] Since the Saha- ra-region did not have valuable trading goods for the merchants of the $16-18^{\text {th }}$ centuries, the establishment of the sphere of interest in the

Sahara-region took place only in the first half of the $18^{\text {th }}$ century, when the Spanish crown and the sultan of Morocco settled it in 1727. [3] After 1884 Spain extended its influence over the internal territories, but first drawing the borderlines to separate the Spanish and the neighboring French zones from each other was necessary. The question was solved in Paris in 1900. [7] The complete pacification of the region was a slow process, it took until 1938. [13]

According to the status of international law in the $19^{\text {th }}$ century, Spain undoubtedly had the right to gain rule over the province, which was conquered mainly by military force. The ICJ adjudged in 1975, the first step in the conquest of Río de Oro was taken by the Spanish king, when he declared he would take under his protection the land of Río de Oro in the name of the Spanish crown, with a settlement with the local chieftains. [6]

\footnotetext{
2 International Court of Justice
} 
Since the rules of international law are, albeit it slowly, changing, in the middle of the

$20^{\text {th }}$ century all the colonizing powers had to face the fact, that their colonies would like to gain and practice the right to self-determination. It was the same situation in the case of Western Sahara. Nonetheless, while the neighboring and other African countries stepped on the road of independence, in Western Sahara a special "pending legal situation" was created due to the invalid Madrid Accords and the following Moroccan and Mauritanian invasion and occupation. The intruders stepped into a situation, where the Saharawies had already stepped onto the road to self-determination, but after the invasion there was no chance to hold the promised referendum about independence. The referendum, which should not have been postponed, is still delayed, while the struggle of the Polisario Front ${ }^{3}$ and the Moroccan army resulted in a humanitarian crisis and serious and sequential abuses of human rights. The civil war held up until 1991, when the parties declared a cease-fire after long preparations, and the UN adopted the resolution of the peacekeeping mission called MINURSO. ${ }^{4}[14]$

\section{Angola}

The Portuguese colonized the coast of Angola in the $15^{\text {th }}$ century and entered into relations with the state of Bakongo, which ruled the Northern part of what is nowadays Angola; later on Portuguese merchants started to trade with slaves. Luanda, the first European headquar- ters, was established in 1575, later it became the capital city of Angola. Under colonial rule many tribes and ethnic groups lived there. The settlements of Mbundus was located on the seashore region, south from the borders of Congolese conquest. The main territories of the Ovimbundus were located in the inner lands and on the southern and southeast part of Ango- la. European settlers moved in the new Portuguese domains relatively late, but in the second half of the $20^{\text {th }}$ century, their population reached 300 thousand and a new, influential mestiço class was formed, which adopted the Portuguese culture and latched onto colonial trade and got involved into the administration of the overseas province. [15]

Colonial independence movements of the fifties swept through Africa, and Angola also made an attempt to earn the right to self-determination. The first movements were started in the northern region of the country with the leadership of Holden Roberto. His organization, the FNLA ${ }^{5}$ built foreign relations and gained support and weapons. Despite the support of China and the CIA for a while, the movement slowly ended. [15] In the central regions of Angola, the clerisy, which governed the country at that time, formed a quite mixed movement with a membership which followed Marxist ideology - the MLPA. ${ }^{6}$ The third faction was based on a territory inhabited by the people of Ovimbundus. The $\mathrm{UNITA}^{7}$ was fairly nation- alistic and bore marks of chauvinism. [15]

When the Portuguese started the negotiations for independence and the evacuation of An- gola in 1974 there were three main group of people, two distinct ethnic groups and one with European origins, and each of them had a different point of view about the future of Angola. In 1975 a bloody civil war started in order to take total control over the state. FNLA units

3 Frente Popular de Liberación de Saguía el Hamra y Río de Oro - Popular Front for the Liberation of Saguia el Hamra and Rio de Oro

4 United Nations Mission for the Referendum in Western Sahara (United Nations Security Council Resolution 690)

5 Frente Nacional de Libertação de Angola - National Front for the Liberation of Angola

6 Movimento Popular de Libertação de Angola - People's Movement for the Liberation of Angola

7 União Nacional para a Independência Total de Angola - National Union for the Total Independence of Angola 
came into action and started to march southwards, while the UNITA established strong po- sitions on its own area, on the southern and south-eastern part of the country and entered into relations with the government of South Africa. The third party was supported by the Soviet Union and Cuba who sent weapons, military advisors, and later fighting troops. The MPLA supported by Cuban soldiers threw back the attacks of FNLA and made a "king" of Agostinho Neto, then they formed a new government. [15] As the FNLA not only suffered defeat but ran out of its money, it was not able to pay the wage of mercenaries and retreated from the battlefield, but still continued to be active in public life. [16]

The war proceeded intermittently until 1987 between the two biggest struggling parties, the MPLA and UNITA, when the MPLA started a military campaign supported by an actively fighting Cuban division. It was the Operation Saludando Octubre which was stopped by the UNITA and its South African allies, but after the fall of the Apartheid regime in South Africa, the Government defeated the enemy, which ruled the southern regions of the country and was supported by South African troops, in the battle of Cuito Cuanavale. South Africa was indirectly interested in the conflict through Namibia. When the parties admitted, neither of them was able to defeat the other, they started to negotiate, in 1990 and in 1991, they finally came to an agreement. The parties agreed on the hold a free election, form a joint army and introduce a market economy. All this was however in vain, there was no definite winner of the 1992 elections. José Eduardo Dos Santos collected the majority of the votes, but his win was not absolute and it was discredited by the opposition. The two big sides stayed strong in their own hinterlands. The standoff turned into armed conflict again, UNITA, which secretly postponed the disarmament, achieved quick success in a surprising offensive, conquering two third parts of the country. [17] The government forces braced themselves and struck back, while the international community pressured UNITA, then turned away from the leader of UNITA, Jonas Savimbi. [17]

The rebels continued the struggle in spite of the international pressure and embargo due to the rich diamond mines located on their territories. The "blood diamonds" exploited by UNITA gave $10 \%$ of the world diamond production at that time. Not only the UNITA, but the MPLA were able to count on the rich mineral resources of Angola, the MPLA acquired income from the selling of fossil oil, which was more than enough to spend on military ex- penditures, since in the nineties Angola has been the second biggest oil exporter in Africa after Nigeria with 750 thousands of barrels per day. [16]

In spite of the new peace plan, called Lusaca Treaty and several UN missions the strug- gling parties were not able to create peace, the struggle continued, even though the sanctions of the international community made the rebels weaker, who lost their leader in 2002 which finally forced them to sign the peace. [16]

\section{Namibia}

The third conflict is about the calvary of Namibia, which - at least in some ways - imitates the situation of Western Sahara. Both are really interesting in the scope of international law, consisting of a lot to think about. The similarity is that Western Sahara and Namibia were former colonies of a European power, which abandoned its colony, later a neighboring power arrived into the vacuum. However, in the case of Western Sahara it has happened in a trou- bling fashion, in case of Namibia South Africa gained the territory legally. Let us see, how! 
The coast of South-West Africa was approached by the Portuguese first, but - as it hap- pened in Western Sahara the desert region did not arouse their interest. English and Dutch sailors, sailing towards the Cape of Good Hope, established settlements in South Africa. [18] In the $19^{\text {th }}$ century, German missionaries arrived into South-West Africa, where they used the rivalry of indigenous Hereros and Namas and established German South-West Africa. [19]

After unification, the German Empire achieved spectacular economic growth and created several new and retrograde concepts. There appeared not only the so-called living-space theory - according to the first plans, they wanted to create it by building up a colonial em- pire [19] - there were also such pseudo-scientific thoughts like social Darwinism and eu- genics allowing their users to create the genetically perfect, disease resistance Aryan genus, which would have a soul above all the other human races.

After German settlers got involved in a clash with the native Hereros - the uprising ab- origines were defeated in 1904 - the "Herero-genocide" started. Germans massacred the native inhabitants of the colony or enclosed them into concentration camps. After the horrible atrocity - which was regrettably only the first attempt at genocide in the $20^{\text {th }}$ century - the number of the Hereros decreased to 15 thousand. [20]

During World War I Africa also became a battle-field where European powers fought against each other. The troops of the Union of South Africa - which unified as a British dominion in 1910 - marched into the territory of German South-West Africa in 1915, where they deported the German citizens into concentration camps. [21] The region was no longer a German colony, it fell under South-African occupation. In the Treaty of Versailles Germany gave up and surrendered its former colonial territories, Namibia as Mandate territory fell un- der the influence of South African administration. The new possessor, South Africa gradually tried to annex the province and went beyond the power delegated by the League of Nations again and again. [21]

The situation is more or less similar to Western Sahara. Here and there a new occupying power arrived substituting the former colonizer, but though the case of Western Sahara and the Moroccan invasion was based on an invalid international agreement, the South African administration was based on a completely legal mandate given by the League of Nations. Yet it is also a parallel, if we pull the cloak of international law from both of the cases, we can see the fact, either in Western Sahara or in Namibia that there was a simple aspiration to conquer a territory, because as Morocco and Mauritania divided Western Sahara was evacuated by Spain according to the Treaty of Madrid, the victorious great powers of World War I shared the colonies of the Central Powers among each other in different type of pacts. The only dif- ference was the newly established League of Nations observed and controlled the occupation and administration. [22]

Mandate areas are divided into three types according to the development index of their population, how mature they are to practice self-determination. Namibia was a Class C man- date, so the administrating power, Union of South Africa, was allowed to consider in princi- ple the territory as its own integrant part, but the mandatory power had to protect the province from the external attacks, and it was obliged to facilitate the advance of development and self-determination. [22]

After the end of World War II, the role of the League of Nations was taken over by the United Nations, the mandates became United Nations Trust Territories. The main principle was the same, the UN tried to give an acceptable formula for the division of former colonies 
and to transform and reorganize the mandate territories. Namibia stayed under South Afri- can administration, moreover the South African government conceived, with the end of the League of Nations, the obligations of mandatory powers were automatically repealed, so South Africa was not obliged to make a contract in case of Namibia, as it had already been annexed. [22] As a matter of course, the international community did not accept this point of view. A long struggle was started, the International Court of Justice announced, it is not pos- sible to force South Africa to make a trust agreement against its will, later, when Ethiopia and Liberia took action against South Africa the ICJ assessed, neither Ethiopia nor Liberia had the legal privilege for litigation. After the court's decision the UN took solving the problem in hand. In 1966 it revoked the mandate and rights of trusteeship from South Africa in Res- olution 264 (1969), then the ICJ declared, after revoking the mandate of trusteeship, South Africa possesses Namibia without a legal basis, so it has to give it up and evacuate. [22]

About the status of Namibia not only the international community and South Africa, but its population also had a point of view, and they did not wait for things to take a turn for the better. In the sixties the first resistance movements were formed against the apartheid regime. The strongest one was the SWAPO, ${ }^{8}$ which founded its armed wing of resistance in 1966, it was the People's Liberation Army of Namibia. [18] Until 1970 the rebels re-enforced they army with international support, while the occupying power created a "counter-army" rely- ing on the white people - mainly the Germans - of the Namibian population. With this reac- tion the South African regime sowed the core of civil war, since then the people of Namibia fought not only against the South African army, but the struggle began between the armed wing of SWAPO and the opposite army, the South-West African Territorial Force. [18] In the meantime the Namibian civil war intensified into an international conflict, because South Africa got involved in the civil war in the neighboring country, Angola, moreover, suffered defeat, which forced the South African regime to start negotiations in order to solve the Na- mibian crisis. The war in Namibia ended contemporaneously with the fall of the apartheid regime, when Namibia declared its independence on the $21^{\text {th }}$ of March in 1990. [18]

\section{Central African Republic}

During its history, the Central African region was quite busy. Several people chose to live in, the area, especially Muslim powers tried to extend their influence over it. Since the $16^{\text {th }}$ century, European and Arab slave-traders deported around 2 million people. [23] In the $19^{\text {th }}$ century French gained a foothold at the frontier of Islam, later on they integrated the region rich in minerals and unified it into a greater entity, so-called French Equatorial Africa with the name Ubangi-Sari. [23]

At the beginning of this essay it was described how the great powers drew the internal border-lines in Africa. The Treaty of Fez from 1912 fits well into the row of bilateral treaties mentioned above. In this agreement France gave up around 290 thousands square kilometers and gave it over to the German Empire. This territory was integrated into the colonial empire of the German emperor until the end of World War I. During the Great War French troops recaptured the ceded territory, moreover they conquered the neighboring German New Cam- eroon. [23]

8 South West Africa People's Organization 
When Ubangi-Sari became independent in 1960, the possibility of creating a Central Afri- can Union, a sort of United States of Africa, emerged, which would have united not only the former French colonies but the neighboring Belgian and Portuguese territories as well. The creation of such a prestigious confederation was ended by the mysterious and sudden death of Barthélemy Boganda. [23]

Instead of becoming a democracy, after five years the country transformed into a military dictatorship, since Captain Jean-Bédel Bokassa seized power, then he arbitrarily crowned himself emperor. The dictator was removed by the French in 1979, his place was taken by the former president, David Dacko. [23] In spite of the regime-change, political tension re- mained, which was followed by another military coup in 1981. The ethnically diverse coun- try continued to crumble, although in 1993 an election was held and they tried to bring into practice the multi-party system again. This instability was due in no small part to the intrigue of French diplomacy. [23] The civil war inspired the neighboring countries to reconcile and make peace, which resulted in several peace-making interventions, but unfortunately these missions were not able to provide peace, however the UN also adopted a peacekeeping-man- date, the so-called MINURCA. [23] The peace-aspirations did not reached their goals, the civil war continued, it even spread over and infected the neighboring Darfur and Chad, and hence the UN sent a new humanitarian mission to Central Africa. Later on the European Union followed the example. In the chaos general François Bozizé, who was in power since 2003, won the Bush War lasting until 2008 and remained in power. [24] In 2012 the pres- ident had to confront a new group of insurgents, it was the so-called Séléka led by Michel Am-Nondokro Djotodia. [23] The Séléka was an allied assembling of rebel militia factions, which consists of not only the Central African Alliance for Revival and Rebuilding, the Pa-triotic Convention for Saving the Country rebel groups, but the Popular Front for Recovery from Chad as well. [24] Their activity is financed by the income coming from illegal diamond and ivory-trade. [25]

Séléka consists of mainly Muslims, while the population of the country is more than $70 \%$ Christian or belong to different tribal religions, this directly led to atrocities based on religion after Séléka took power. As an answer, Christians created the anti-Balaka voluntary militia, it exceeded its scope of duties and attacked and sacked Muslim villages. [25]

President Djotodia was not able to overcome the situation, while the UN gave authori- zation to the African Union to lead a new peacemaking mission ${ }^{9}$ which was adopted by the Security Council in the Resulotion 2127. [25] Djotodia was banished by the international community, he escaped to Benin, and his place was taken by the mayor of Bangui, Cathrine Samba-Panza on $23^{\text {th }}$ of January in 2014. [25]

\section{The Four Mandates}

The international community has made several efforts in order to solve the crises mentioned above. In case of the four conflicts numerous missions were started by the United Nations as well. Hereinafter we are going to survey, where and what exactly did the UN do in order to arrange the conflicts, what is missing from the mandates and why?

9 MISCA-African-led International Support Mission in the CAR 


\section{MINURSO}

As we can see in the name of this particular mission - United Nations Mission for the Ref-erendum in Western Sahara [26] - the UN created this mission as a part of a bigger settle- ment ${ }^{10}$ to give the Saharawi people a chance to practice their right to self-determination. The Security Council Resolution 690, which was adopted on 29 of April 1991, declared, that the promised referendum would be transected in co-operation with the UN and the Organization of African Unity. Technical execution would be brought into effect by a peacekeeping mis- sion, which was mandated to accomplish the following tasks:

- organizing and ensuring the promised free and fair referendum, which is going to be transacted by the UN and the Organization of African Unity,

- observing the negotiated cease-fire,

- verifying the reduction of Moroccan troops,

- monitoring the confinement of Moroccan and Polisario troops to designated locations,

- taking steps in order to release all Western Saharan political prisoners or detainees,

- observing the exchange of the prisoners of war in co-operation with the International Committee of the Red Cross,

- executing the program adopted by the $\mathrm{UNHCR}^{11}$ in order to facilitate the repatriation programme,

- identify and register all citizens in Western Sahara who are qualified and entitled to vote. [26]

As we can see, there is a missing part, a very important mechanism is absent from the settlement of such conflict where a "legendary" amount of abuses of human rights were com- mitted. Indirectly there are some of rules protecting human rights. The referendum, which is the main intention of the mission, could be the only way to guarantee the materialization of one of the most elemental human rights, namely the right to self-determination. It is also indirect, but releasing the prisoners of war and other political captives it is protecting the right to personal freedom. However the protection of human rights is not mentioned expressly its regularization has been postponed, while the mandate of Minurso has been renewed several times, not to mention the fact, since the beginning of the mission, numerous reports about human rights abuses were issued by human rights organizations.

Since 1991 the mandate of MINURSO was renewed or extended 44 times, [27] the mon- itoring system of human rights is still missing in spite of the initiations and attempts. In 2014 the Human Rights Watch made a request in its letter to the UN Security Council to extend the mandate of MINURSO with a mechanism in order to protect and observe the situation of human rights, but it was cancelled at the time. [28] In April 2015 the mandate was renewed again, the issue of the monitoring system was in the agenda, which was supported among others by Norway, [29] but it was declined again. [30]

In an armed conflict human rights are regrettably one of the last aspects being respected by the parties, which is a small wonder, as a violation of human dignity, taking lives and ev- ery other similar atrocity is attached to human conflicts. Arranging such clashes depends on the will of high politics. As a matter of course both parties have supporters who are capable of setting a bar against the aspiration of the others if necessary.

10 The settlement was adopted by the Kingdom of Morocco and the Polisario Front on 30 $0^{\text {th }}$ of August in 1988.

11 United Nations High Commissioner for Refugees 


\section{UNAVEM I-III and MONUA}

The missions of the UN were never built following a united schema. They are oriented to the specialties of the given conflict, many times only one mission is not enough to solve the problem. In the Angolan Civil War several missions were started. First was the UNAVEM, ${ }^{12}$ which was adopted by the Security Council Resolution 626. (1988). [31] This time the object was to secure and observe the withdrawal of Cuban troops from the country according to the schedule which was adopted by the Angolan and Cuban governments. Because the operation came to an end before the deadline, the UNAVEM I mission successfully reached its purpose in 1991. [32]

Comparing MINURSO to UNAVEM II is truly interesting for us. In the longest armed conflict of Africa, the parties, who endeavored to make peace, adopted the so-called Peace Accords for Angola (Bicesse Accords) which consist of similar terms to the peace plan of Western Sahara. First and most importantly the belligerents concluded a ceasefire and agreed on the condition, that the truce will be verified by the peacekeepers of international commu- nity. In the ceasefire agreement disbanding of paramilitary units was implied and the parties settled about a mechanism in order to investigate the existence and use of biological weap- ons. [33] The peace plan dealt with a joint Angolan army which would have been merged from the two hostile armies. [33] The plan regarded not only the capitulation, but aimed to ensure the peaceful political transition with the participation of UNITA. [33]

In the practical implementation of the peace plane the parties called for the help of the UN, which established the second UNAVEM Mission on 30 $0^{\text {th }}$ of May 1991. [34] The new mandate held up until 1995, its function was to keep up and observe the negotiated peace, help the reorganization of the Angolan army, deliver the humanitarian aid and to execute some administrative tasks. [35] Making peace was a very slow process, UNITA did not ac- cept the results of the election in 1992. The mandate of the Mission was renewed five times until 1995, when because of difficulties, it was overruled by the mandate of UNAVEM III in

1995. [36]

Because the conflict continued in the first half of the nineties, the former settlement was not really respected and observed by the parties, although an election was held, as I referred to it before, UNITA did not accept the result. The number of the peacekeepers of UNAVEM II was too few, to make peace in the civil war which had lasted for decades, and it was also an unrealistic expectation to unite opposite hostile soldiers in the same army. [17]

In 1994 under the pressure of international community the parties reopened the negoti- ations, which resulted in the so-called Lusaka Protocol with a cease-fire similar to the for- mer peace-settlement. The issue of the army was a neuralgic point again. According to the Protocol, from the force of UNITA 5500 soldiers would have been enrolled in the force of the Angolan police, further 1200 soldiers would have been integrated in the Rapid Reaction Police. For the senior officers of UNITA the Protocol offered high ranking positions in the Angolan army. Furthermore for the members of UNITA the Protocol granted higher and more influential political and economical positions than the former settlement. In reforming the government, they sought balance, the two great rivals should have entered a coalition to govern Angola in that way. [37]

12 United Nations Angola Verification Mission 
The task of UNAVEM III Mission, [38] which was established in order to execute the Lusaka Protocol, was to observe the cease-fire, to facilitate building up a nation-wide admin- istration, to promote the recovery of the economy, to follow with attention the neutrality of the new Angolan police, participation in mine clearing, and last but not least to support and oversee the second round of elections. [39]

The Angolan Civil War was a complete failure for the peace-makers in the nineties, in spite of their aspirations. They created two peace plans in vain, they established three UN Missions, and they had to adopt a third mandate in 1997. The mandate of MONUA ${ }^{13}$ [40] was adopted on $30^{\text {th }}$ of June 1997, its function was diversified. Likewise in the previous mandates, in MONUA there was also a priority to reconcile the rival enemies, integrate them in a common government, set in order the issue of Angolan army and police, ease the human- itarian crisis. The necessity of the protection of human rights, the revelation of abuses, and promotion of the activity of human rights agencies were firstly mentioned. [41] The mandate of MONUA ended in 1999. The conflict was too deep and complicated, it held until the first half of the Millennium years. It "outlasted" several UN Missions in spite of all the efforts made by the international community.

\section{UNTAG}

In contrast with Angola the conflict in Namibia finished quickly due to the fall of the apartheid regime in South Africa. The Namibian mission of the UN was widely empowered by Reso- lution 632 of the Security Council. [42] Not only the situation of Namibia, but the mandate of the UN Mission takes after the case and the peace plan of Western Sahara, because in the first place the mandate of UNTAG was to organize and transact a free and fair referendum. To effectively hold elections, South African troops had to leave the country first, the rebels needed to be disarmed, while the peacekeepers of UNTAG observed the procedure. [43] The mandate also rules over the activity and monitoring of the new Namibian police, declares that the racial discriminating acts passed by the occupying regime to be annulled, also declares amnesty and prescribes the release of prisoners of war and the repatriation of South-West African refugees, and disposes the registration of qualified voters. [21]

The mission of UNTAG led to success in a short time due to, not only the wide entitlement, but the advantageous geopolitical situation and the co-operation of the parties as well.

\section{MINUSCA}

On $10^{\text {th }}$ of April 2014, the UN undertook to solve the civil war in the Central African Re- public with a multidimensional peacekeeping mission. MINUSCA, ${ }^{14}$ it incorporated a pre- vious peacekeeping mission led by the African Union, the so-called MISCA. The mandate of the mission launched by Resolution 2149 of UN Security Council [44] consisted of the following: first and most important the unprejudiced protection of civilians from violence, with special emphasis of women and children, close co-operation with the humanitarian and human rights organizations. Further function of the mandate to assist the peaceful political transition, maintain the territorial integrity of the Central African Republic. It is important to

13 United Nations Observer Mission in Angola

14 United Nations Multidimensional Integrated Stabilization Mission in the Central African Republic 
emphasize, the mandate of MINUSCA expressly deals with the protection and monitoring of human rights. The peacekeepers were authorized to explore and report the human rights abuses committed by the soldiers of Seleka and anti-Balaka, to expose the reveal the of- fenders in order to call them to account. Further aspiration to help the disarmament of rival militias, the reintegration of the rebel soldiers into society, and to assist the repatriation of the persecuted citizens. [45]

\section{Summary}

The analyzed four conflicts and the answers given by the international community draw at- tention to several factors. On one hand the historical heritage of Africa is too heavy a burden on the underdeveloped social, economic and political systems, the African states are hardly able to cope with the difficulties on their own. In every, or at least in most of the cases the in- ternational community tries to give an answer to the emerging conflicts, but the effectiveness of these depend on several factors. It depends for example on the money which is intended to be paid by the UN on peacekeeping mission, or - what is more important because the ques- tion of money depends on the political intention - how interested the decision-makers are in resolving the conflicts. The South-West African situation was ended fast with the fall of the South African apartheid regime, though it is true, until the regime was in power, South Africa artfully avoided giving up the occupied province. In the Angolan crisis many peacekeeping missions were launched, for the lack of results not only the great powers were responsible, but it is a fact and beyond dispute, that behind the UNITA and the MPLA, the powers of the two poles aligned. Their intervention did not resolve the conflict but made it longer.

From the analysis it has turned out, that the conflict management of the UN is following a kind of schema, but adjusted to the specialities of the given situation. In a war-time situation it is irrelevant to expect from the struggling parties to pay attention to the protection of human rights, hence in every conflict the first step has to be to make peace. As we saw, to agree on the terms of peace is the responsibility of the parties, the international community only can help to organize or host the peace negotiations, or to realize and observe the particular terms.

It was interesting to see, the mandates of UN missions dealt expressly with the human rights and the protection of the civilian population only one time, in the case of Central Af- rican Republic, while in the case of Western Sahara and Namibia the mandates attached the problem only indirectly. In Western Sahara it was the promotion of the Sahrawi people to practice the right to self-determination, while in Namibia repealing the racial discriminatory acts. It is also a useful and interesting experience, that in Central Africa - which is under strong French influence - the UN established a mechanism dealing with human rights in the first mandate, at the same time the same mechanism has been a missing part for a long while in the case of Western Sahara, due to the diplomatic maneuvers of Morocco, which is also enjoying the support of French diplomacy. Of course protection of human rights in war-time can only be the first priority, when the clashes are finished and the peace restored, a more or less effective administrative system is working, which is able to detect and reveal abuses and act against the offenders. 


\section{References}

[1] ASONGAZOH ALEMAZUNK, J.: Post-Colonial Colonialism: An Analysis of International Factors and Actors Marring African Socio-Economic and Political Development. The Journal of Pan African Studies, 310 (2010), 62-84. www.jpanafrican.org/docs/ vol3no10/3.10Post-Colonial.pdf (downloaded: 2505 2015)

[2] SZABÓ L.: Tévhitek és tények a Kongói Demokratikus Köztársaság előtti Kongóról egy történeti áttekintés ürügyén. Afrika Tanulmányok Folyóirat, II 4 (2008), 10-19.

[3] SZABÓ L., ÖLBEI T., WILHELM Z.: Anyaországok és (volt) gyarmataik I. Pécs: PTE Afrika - Amerika - Ázsia Universitas Munkacsoport, 2002.

[4] KENDE T., NAGY B., SONNEVEND P., VALKI L.: Nemzetközi jog. Budapest: Complex Publisher, 2014.

[5] van der LINDEN, M.: The Acquisition of Africa (1870-1914): the Nature of Nineteenth-Century International Law. Heidelberg: Max Plankt Institute, 2015. www.mpil.de/en/pub/ research/details/projects/public_int_law/sovereignty_property_and_trea.cfm (downloaded: $28052015)$

[6] INTERNATIONAL COURT OF JUSTICE: Western Sahara. Advisory Opinion of 16 October 1975. www.icj-cij.org/docket/files/61/6197.pdf (downloaded: 2605 2015)

[7] BESENYÖ J.: A nyugat-szaharai spanyol népszámlálás és az ENSZ. Afrika Tanulmányok Folyóirat, II 2 (2008), 18-29.

[8] 1893 Agreement between Great Britain and Portugal Relative to Spheres of Influence North of the Zambesi. http://treaties.fco.gov.uk/docs/pdf/1893/TS0010.pdf (downloaded: 2905 2015)

[9] 1890 Heligoland-Zanzibar Treaty. http://germanhistorydocs.ghi-dc.org/pdf/eng/606_Anglo- German\%20Treaty_110.pdf (downloaded: 2505 2015)

[10] SZALAI A.: Az államhatár és a nemzetközi jog. http://drszalaianiko.hu/2014/03/19/az- allamhatar-es-a-nemzetkozi-jog/ (downloaded: 3005 2015)

[11] PETERS, A.: The Principle of Uti Possidetis Juris - How Relevant is it for Issues of Secession? In. Self-Determination and Secession in International Law, Oxford: Oxford University Press, 2014. 95-137.

[12] SHAW, M. N.: Nemzetközi jog. Budapest: Komplex Publisher, 2008. [13] BESENYÖ J.: Western Sahara. Pécs: Publikon Publisher, 2009.

[14] BESENYÖ J.: Hungarian logistics specialist working for the UN's Western Sahara mission. AARMS, 71 (2008), 155-165.

[15] KOVÁCSY T.: Angola magánya. Beszélö, 54 (2000). http://beszelo.c3.hu/00/04/09kova. htm (downloaded: 0106 2015)

[16] HORVÁT S.: UNAVEM Misszió - Angola. A békéig vezető út az UNAVEM missziókon keresztül dióhéjban. Nemzetbiztonsági Szemle, 2 Special Issue 2 (2014), 77-87.

[17] BESENYÖ J.: Magyar katonák tevékenysége az angolai ENSZ-békeműveletekben. Hadtudomány, XXIV 3-4 (2014), 63-77.

[18] BESENYÖ J., MOLNÁR E.: A namíbiai haderő. Sereg Szemle, X 3 (2012), 121-133. [19] MOLNÁR E.: A namíbiai történelem sötét foltja: a herero népirtás. Sereg Szemle, XI 2-3 (2013), 212-220.

[20] FERGUSON, N.: Civilizáció - A Nyugat és a többiek. Budapest: Scolar Publisher, 2011. 
[21] BESENYÖ J., MOLNÁR E.: ENSZ békefenntartás magyar részvétellel: Namíbia. Sereg Szemle, X 1 (2012), 133-144.

[22] KOVÁCS P.: Nemzetközi közjog. Budapest: Osiris Publisher, 2011.

[23] BALOGH A., BESENYÖ J., MILETICS P., VOGEL D.: Országismertető - Közép-afrikai Köztársaság. Budapest: Honvéd Vezérkar Tudományos Kutatóhely, Magyar Honvédség Geoinformációs Szolgálat, 2015.

[24] TOMOLYA J.: Közép-afrikai Köztársaság: Mi lesz veled? Szakmai Szemle, 1 (2014), 5-26. [25] MARSAI V.: Válságok Közép-Afrikában II. Polgárháború a Közép-afrikai Köztársaságban. NKE Stratégiai Védelmi Kutatóközpont Elemzések, 4 (2014). http://nit.uni-nke.hu/ downloads/Elemzesek/2014/SVKK_Elemzesek_2014_4.pdf (downloaded: 0506 2015) [26] United Nations Mission

for the Referendum in Western Sahara (United Nations Security Council Resolution 690). www.securitycouncilreport.org/atf/cf/\%7B65BFCF9B-6D274E9C-8CD3-CF6E4FF96FF9\%7D/MINURSO\%20SRES690.pdf (downloaded: 0506 2015) [27] United Nations

Documents on Minurso. www.un.org/en/peacekeeping/missions/minurso/ resolutions.shtml (downloaded: 0606 2015)

[28] Letter to Members of the UN Security Council: Extend MINURSO Mandate to Human Rights. www.hrw.org/news/2014/04/14/letter-members-un-security-counctil-extend- minurso-mandate-human-rights (downloaded: 0706 2015)

[29] Norway supports extension of MINURSO mandate to include human rights monitoring. Sahara Press Service, 0319 2015. www.spsrasd.info/en/content/norway-supports-extension- minurso-mandate-includehuman-rights-monitoring ) (downloaded: 0706 2015)

[30] BETRIÁN, G. R.: Spain and Morocco welcome the extension of MINURSO's mandate. The Diplomat, s.d. http://thediplomatinspain.com/en/spain-and-morocco-welcome-the- extension-of-minursosmandate/ (downloaded: 0706 2015)

[31] UNAVEM I Resolution 626 (1988). http://daccess-dds-ny.un.org/doc/RESOLUTION/GEN/ NR0/541/53/IMG/NR054153.pdf?OpenElement (downloaded: 0906 2015)

[32] Angola - UNAVEM I Mandate. www.un.org/Depts/DPKO/Missions/unavem1/UnavemIM. htm (downloaded: 0906 2015)

[33] Peace Accords for Angola. http://peacemaker.un.org/sites/peacemaker.un.org/files/ AO_910521_PeaceAccordsforAngola\%28en\%29.pdf (downloaded: 1006 2015)

[34] UNAVEM II Resolution 695 (1991). http://daccess-dds-ny.un.org/doc/RESOLUTION/GEN/ NR0/596/32/IMG/NR059632.pdf?OpenElement (downloaded: 1006 2015)

[35] BESENYÖ J.: Magyar békefenntartók afrikai tapasztalatai: Angola és Uganda. Afrika Tanulmányok Folyóirat, V 4 (2011), 112-125.

[36] Angola - UNAVEM II Mandate. www.un.org/Depts/DPKO/Missions/Unavem2/UnavemIIM. htm (downloaded: 10062015$)$

[37] US INSTUTUTE OF PEACE: Lusaka Protocol 1994. Lusaka, 1994. www.usip.org/sites/ default/files/file/resources/collections/peace_agreements/lusaka_11151994.pdf (downloaded: $10062015)$

[38] UNAVEM III Resolution 976 (1995). http://daccess-dds-ny.un.org/doc/UNDOC/GEN/ N95/038/14/PDF/N9503814.pdf?OpenElement (downloaded: 1106 2015)

[39] Angola - UNAVEM III Mandate. www.un.org/en/peacekeeping/missions/past/unavem_p. htm (downloaded: 1106 2015)

[40] MONUA Resolution 1118 (1997). www.un.org/ga/search/view_doc.asp?symbol=S/ RES/1118(1997) (downloaded: 11062015 
[41] Angola-MONUA Mandate. www.un.org/en/peacekeeping/missions/past/monua/monuam. htm (downloaded: 1106 2015)

[42] UNTAG Resolution 632 (1989). www.worldlii.org/int/other/UNSC/1989/6.pdf ) (downloaded: 1206 2015)

[43] Namibia - UNTAG Background. www.un.org/en/peacekeeping/missions/past/untagFT.htm (downloaded: 1206 2015)

[44] MINUSCA Resolution 2149 (2014). www.un.org/en/ga/search/view_doc.asp?symbol=S/ RES/2149(2014) (downloaded: 1306 2015)

[45] CAR - MINUSCA Mandate. www.un.org/en/peacekeeping/missions/minusca/mandate.shtml (downloaded: 1506 2015) 